\title{
EPIDURAL ADMINISTRATION OF ROMIFIDINE FOR SURGICAL ANALGESIA OF BUFFALOES UNDERGOING STANDING FLANK AND UDDER SURGERY.
}

\author{
Mohamed Marzok ${ }^{1}$, Shaaban Gadallah ${ }^{2}$, Sabry El-Khodery ${ }^{3}$ GMaysa Anwar ${ }^{4}$ \\ ${ }^{1}$ Department of Surgery, Faculty of Veterinary Medicine, Kafr El-Sheikh \\ University, Kafr El-Sheikh 33516, Egypt. \\ ${ }^{2}$ Department of Surgery Anaesthiology \& Radiology , Faculty of Veterinary \\ Medicine, Cairo University. \\ 3 Department of Internal Medicine and Infectious Diseases, Faculty of \\ Veterinary Medicine, Mansoura University. \\ ${ }^{4}$ Teaching hospital of faculty of Veterinary Medicine, AlexUniversity.
}

\begin{abstract}
The aim of the present study was to evaluate the efficacy of romifidine as epidural analgesic for standing flank and udder surgery in buffaloes. For this purpose, romifidine was administered at dose 50 $\mu \mathrm{g}$ kg-1 via epidural space in 20 female buffaloes had to undergo flank and udder surgery. Buffaloes were examined for time to onset of analgesia, anatomic extent of analgesia, all systemic reactions to the drug and the total procedure time. Moreover, heart rates, rectal temperature, respiratory rates, feces and urine production as well as the degree of analgesia, sedation and ataxia were recorded at different intervals before (baseline) and after administration. In all animals, epidural injection of romifidine induced a significant decrease in the heart rate. However rectal temperature and respiratory rate didn't show any significant changes. There was a significant increase of analgesic effect with time progress. For all animals, the peak analgesic period was extended from 15-240 minutes post- administration of romifidine. Ten minutes after epidural
\end{abstract}


administration, all buffaloes began to show signs of systemic sedation (mild sedation, score $=1$ ). Maximal sedative effect occurred between 30 and 180 minutes after epidural administration of romifidine. All buffaloes developed moderate ataxia (score 2) 15-20 minutes following epidural administration of romifidine and it lasted for up to 240 minutes. All these results provide evidence for a potential costeffective intra- and postoperative method of analgesia for abdominal and udder surgery in buffaloes, while allowing the patients to remain standing. Therefore, romifidine might be promising as an analgesic agent for buffaloes even for major abdominal surgery.

Keywords: Romifidine; Epidural analgesia; Buffaloes.

\section{INTRODUCTION}

Currently, various local anesthetic techniques for providing anesthesia in standing bovine undergoing flank and udder surgery have been described (Skarda 1993). Each of these techniques has various advantageous and disadvantages, but the ideal technique would be one that provides complete anesthesia of the flank and the udder following injection of a small volume of anesthetic and is not associated with any adverse effects (Lee and Yamada 2005). Depending on the site of injection, different types of epidural analgesia are distinguished. In segmental epidural analgesia the local analgesic is injected into the thoracolumbar (T13-L1) or first lumbar (L1-L2) intervertebral space. This provides analgesia of the flank useful for surgeries, such as caesarean section, rumenotomy, or laparotomy (Skarda and Muir 1979). This technique is difficult to be performed and the reported complications were ataxia or recumbency due to inadvertent subarachnoid injection (Skarda 1996). The lumbosacral (L6-S1) epidural analgesia is easier to be performed (Lewis et al. 1999). 
According to Seiferle (1992), the spinal cord reaches as far as the first sacral vertebra. Therefore, the risk of damaging the spinal cord during segmental or lumbosacral epidural anaesthesia does exist (Skarda 1996). For this reason these techniques are not widely established in cattle practice. On the contrary, caudal epidural analgesia is routinely used in bovine for a variety of surgical and obstetrical procedures and may be described as "high" or "low" (Benson and Thurmon 1981). Both techniques employ the injection of a volume of local anesthetic solution into the sacrococcygeal (S5-Co1) or first coccygeal (Co1-Co2) intervertebral space. High caudal epidural analgesia involves the administration of relatively large volume of local analgesic to provide analgesia to the more cranial body regions and is used for performing hind limb and udder surgery (Turner and McIlwraith 1982). Low caudal epidural analgesia is more frequently used than high epidural technique and differs only in the volume of local analgesic solution injected. This technique produce analgesia restricted to the tail, anus, vulva and perineal area without compromising the motor function of the pelvic limbs (Caron and LeBlanc; 1989).

Several local anesthetic drugs are used to produce epidural anesthesia, such as lidocaine, bupivacaine, ropivacaine, and mepivacaine (Skarda 1996). Epidural analgesia is obtained also with opioid agonists, alpha $2^{-}$ adrenergic agonists, and ketamine (Natalini and Driessen 2007).

Caudal epidural analgesia using local anesthetics is produced by inhibition of conduction of impulses of sensory nerves located in the cauda equina (Levy 1974). Local anesthetics show little discrimination among fibers blocking sensory, sympathetic, and motor fibers. Depending upon the placement and volume of local anesthetic, both sensory and motor neural fibers may be affected (Turner and McIlwraith 1982). 
Occasionally, the loss of sensory and motor function is desired to facilitate completion of any procedure. Frequently, however, it would be advantageous to block the sensory fibers without affecting motor function, thereby allowing the animal to remain standing (Zaugg and Nussbaum 1990).

It has been shown in a number of species that opioids and alphaadrenergic agents produce selective caudal epidural analgesia, by activating specific spinal receptors (Cousins and Mather 1984; Yaksh 1985; Fierheller et al. 2004; Kinjavdekar et al 2007; Ishii et al 2008). Stimulation of these spinal receptors results in inhibition of rostral transmission of nociceptive (pain) impulses. Therefore a potential advantage of such agents is the production of selective sensory blockade, without the unfavorable depression of motor or autonomic neurons. Romifidine is an amino -imidazolidine derivative, selective alpha 2adrenoceptor agonist drug (Adams 2001). It has been administrated IV, IM, and epidurally in horses (England et al. 1992; Gasthuys et al. 1996; Kerr et al. 1996), dogs (England et al. 1996; Lemke, 1999), cats (Selmi et al. 2004), cattle (Prado et al. 1999; Fierheller et al. 2004), sheep (Celly et al. 1997) and goat (Aithal et al. 2001; Amarpal et al. 2002; Kinjavdekar et al. 2006), and it has been shown to have systemic and analgesic effects similar to other alpha- 2 agonists. In cattle, romifidine appears to have similar effects as xylazine, although it may provide more rapid onset and greater duration of analgesia (Massone et al. 1993). To the best of the authors' knowledge, the use of romifidine for epidural analgesia in buffaloe has not been described. Therefore, the objective of this study was to evaluate the effectiveness and usefulness of romifidine as an epidural analgesic in buffaloes for surgical procedures cranial to the perineal region. 


\section{MATERIALS AND METHODS}

Twenty mature female buffaloes at 1.5 to 7 years of age $(5.92 \pm$ $2.15)$ and weighed $330-470 \mathrm{~kg}(402.57 \pm 74.27)$ were used in this study. All animals under investigation were admitted to both Universities of Kafr-Elsheikh and Cairo Veterinary Medicine Teaching Hospitals and underwent standing flank or teat surgical procedures. All buffaloes considered healthy on the basis of results of physical examination. Each animal had a complete physical examination prior to and at the end of the study, as well as being continually monitored throughout the study. Romifidine (Sedivet, $10 \mathrm{mg} / \mathrm{ml}$, Boehringer Ingelheim, Vetmedica $\mathrm{GmbH}$, Germany) was administrated epidurally in each buffalo.

Each animal was restrained in standing position in a stanchion, the hair over the epidural injections site was clipped, and the site was surgically prepared. Each animal received $50 \mu \mathrm{g} \mathrm{kg}$ of romifidine (romifidine dosages were diluted in sterile saline to a final volume of 20 $\mathrm{ml}$ ) injected directly into the epidural space between the first and second coccygeal vertebrae (the first intercoccygeal pace), using 18 gauge, 4 $\mathrm{cm}$ hypodermic needle. The needle was inserted at an angle of $45^{\circ}$ to the skin surface, directed anteriorly and venterally to a depth of $2 \mathrm{~cm}$. Correct needle placement was verified by detecting negative pressure with the hanging drop technique (Skarda 1986) and negligible resistance to injection. Following placement of the needle, the solution was administered into the epidural space by slow injection. The time of administration was noted, and the surgery site was clipped and prepared for surgery. 
After administration of romifidine, the following parameters were recorded; time to onset of analgesia, anatomic extent of analgesia, all systemic reactions to the drug and the total procedure time. Heart rates, rectal temperature, respiratory rates, feces and urine production as well as the degree of analgesia, sedation and ataxia, were recorded immediately (time 0) pre-administration and at 5, 15, , 30, 45, 60, 90, 120, 180 and 240 minutes and again at 6,12, 24 and 48 hours after making the epidural injection. At each monitoring time, the occurrence of feces or urine production during the preceding interval was recorded.

In addition to watching for pain (nociceptive) response during the surgical procedure, also the onset, depth and margins of analgesia was qualitatively assessed by observing the animal's response to skin pinpricks with an 18 gauge hypodermic needle. The sedative and analgesic effect was evaluated and recorded blindly on visual analogue scale by single clinician at the same time points. The buffalo's eyes were covered at the time of stimulation to avoid any visually provoked response. The wounds created by the skin pricks were cleaned and then treated with a topical antiseptic solution. Depth of analgesia was graded on a score system from 0 to 3 as described in horses by Jöchle and Hamm (1986); 0, no analgesia (strong response to noxious stimulus, such as kicking); 1, mild analgesia (moderate response, such as turning the head toward the site of stimulation); 2, moderate analgesia (very weak and occasional response); 3, complete analgesia (no response to noxious stimulus). The time of onset and score and duration of analgesia were recorded for 240 minutes post-administration. Time to onset of surgical analgesia was taken as the time from injection to the time when the animal failed to respond to pinpricks along the incision site. Total procedure time was the time from epidural administration to the 
completion of surgery. Epidural (surgical) analgesia was assessed to be poor if the animal responded to pinprick or incision in a violent manner, or demonstrated signs of distress. Analgesia was assessed to be adequate if there was minimal response to incision, i.e., switching feet, lifting hind leg, or turning head to see the incision site. The analgesia was assessed to be good if the animal showed no response to surgical stimulations.

Sedative effect of romifidine was assessed subjectively on a scale 1 to 5 (Table 1). The time of onset and score of sedation were recorded immediately after drug administration. The duration (minutes) of sedation was determined as the time from start of sedation effect to return to score of zero. Sedation was considered to be acceptable if the buffalo developed a low head carriage, ptyalism, and decreased reaction to external stimuli, but showed no signs of ataxia (sedation score $=1$ ).

Table (1): Sedation scoring system for buffaloes receiving romifidine $\left(50 \mu \mathrm{g} \mathrm{kg}^{-1}\right)$.

\begin{tabular}{|c||c||l||}
\hline Score & Criteria & \\
\hline \hline 0 & No sedation & $\begin{array}{l}\text { Subjective assessment } \\
\text { of movement, head and neck carriage, eye alertness, lid apposition, tongue } \\
\text { position, postural tone, stance) }\end{array}$ \\
\hline \hline 1 & Mild sedation & $\begin{array}{l}\text { Buffalo appears slightly changed from normal attitude (slightly decreased } \\
\text { frequency and velocity of movement, lower head carriage, deviation of the neck, } \\
\text { reduced eye alertness, ptosis of upper lid, hanging or protrusion of the tongue out } \\
\text { of the mouth, slight base-wide stance, slightly relaxed postural tone, ptyalism) }\end{array}$ \\
\hline \hline 2 & Moderate sedation & $\begin{array}{l}\text { Buffalo appears moderately changed from normal attitude (moderately decreased } \\
\text { frequency and velocity of movement, obvious head ptosis, increased base-wide } \\
\text { stance, appearance of crossed legs, buckled knees and/or fetlocks, more relaxed } \\
\text { postural tone, swaying of the hind legs) }\end{array}$ \\
\hline \hline 3 & Deep sedation & $\begin{array}{l}\text { Markedly decreased frequency and velocity of movement, marked ptosis of the } \\
\text { head and upper eyelid, markedly deviation of the neck, greatly reduced eye } \\
\text { alertness, extreme protrusion of the tongue out of the mouth, markedly increased } \\
\text { base-wide stance, increased occurrence and severity of crossed legs, buckled } \\
\text { knees and/or fetlocks, pronounced loss of postural tone, attempts to lie down but } \\
\text { aroused with stimulation) }\end{array}$ \\
\hline \hline
\end{tabular}


The degree of ataxia was assessed by the degree of resistance to lateral push on the pelvis, observing the position of animal's hind limbs, how much the animal swayed and leaned against the stanchion, the extent of knuckling or flexion of fetlock (metatarsophalangeal) joints and the animal attempt to lie down (Table 2).

Table (2): Scoring system used for description of ataxia after epidural administration of romifidine in buffaloes $\left(50 \mu \mathrm{g} \mathrm{kg}^{-1}\right)$.

\begin{tabular}{|c|c|c|c|c|c|}
\hline Score & Criteria & $\begin{array}{l}\text { Resistance } \\
\text { to push }\end{array}$ & Fetlock flexion & $\begin{array}{c}\text { Swaying and } \\
\text { leaning }\end{array}$ & Attempt to lie down \\
\hline 0 & No ataxia & Strong & None & None & None \\
\hline 1 & Slight ataxia & Normal & None & Slight & None \\
\hline 2 & Moderate ataxia & Decreased & Intermittent & Occasional & $\begin{array}{l}\text { attempt to lie down but easily } \\
\text { coaxed up }\end{array}$ \\
\hline 3 & $\begin{array}{l}\text { Significant } \\
\text { ataxia }\end{array}$ & Weak & Often & Often & $\begin{array}{l}\text { attempt to lie down but } \\
\text { difficulty coaxed up }\end{array}$ \\
\hline 4 & Sever ataxia & $\begin{array}{l}\text { Almost } \\
\text { absent }\end{array}$ & Constant & Constant & $\begin{array}{l}\text { Go down and could not be } \\
\text { Coaxed up }\end{array}$ \\
\hline
\end{tabular}

Statistical analysis- Data analyses were carried out using statistical software program (SPSS for windows Version 15.01, USA). The results are presented as means $\pm \mathrm{SD}$. One-way repeated measures ANOVA was used to determine significant differences between values at different time points. Sphericity assumption and Wilks, Lambda were examined for significance. When a significant difference was found, Bonferroni posthoc multiple comparison test was performed for further evaluation. Differences were considered significant when $\mathrm{P}<0.05$. 


\section{RESULTS}

In all animals, the tail and perineal area become desensitized to a skin prick within five minutes after epidural injection of romifidine. Also, flaccidity of the tail was observed in all buffaloes under investigation. The needle prick analgesia test was sufficient and demonstrated when dermatomes were blocked after epidural administration of romifidine. The most cranial level of spinal nerve analgesia was estimated to be about thoracic segments $\mathrm{T} 1$ and $\mathrm{T} 2$. In all animals, the anatomic level of anesthesia ascended at least to the thoracic segment T4 (Table 3).

Table (3): The evaluation of buffaloes given epidural injection of romifidine $\left(50 \mu \mathrm{g} \mathrm{kg}^{-1}\right)$ to induce surgical analgesia while standing.

\begin{tabular}{|c|c|c|c||}
\hline Procedure performed & $\begin{array}{c}\text { Start of surgical analgesia } \\
(\mathbf{m i n} .)^{*}\end{array}$ & $\begin{array}{c}\text { Length of } \\
\text { procedure (min.) }\end{array}$ & $\begin{array}{c}\text { Cranial extent of } \\
\text { analgesia** }\end{array}$ \\
\hline \hline $\begin{array}{c}\text { Rumenotomy and application } \\
\text { of ruminal canula ( } \mathrm{n}=9)\end{array}$ & $13.0 \pm 2.20$ & $90 \pm 9.35$ & $\begin{array}{c}\mathrm{T}_{1}(6 / 9) \\
\mathrm{T}_{2}(2 / 9) \\
\mathrm{T}_{3}(1 / 9)\end{array}$ \\
\hline cesarean section $(\mathrm{n}=5)$ & $13.0 \pm 2.73$ & $130 \pm 15.81$ & $\mathrm{~T}_{1}(4 / 5)$ \\
$\mathrm{T}_{2}(1 / 5)$
\end{tabular}

*Time from romifidine injection to surgical analgesia, or to maximum area of desensitization.

**Spinal nerve segments innervating anatomic areas that were desensitized to a skin prick

As shown in figure 1, epidural injection of romifidine induced a significant decrease in the heart rate (Wilks, Lambda, $\mathrm{P}<0.01$; Bonferroni test, $\mathrm{P}<0.05)$. Thus the lowest heart rate was recorded at 45 minutes post-administration. However, respiratory rate and rectal temperature didn't show any significant changes. Frequent urination commencing about 60-90 minutes after administration of romifidine was observed during this study. The frequency of urination showed significant increase $(\mathrm{P}<0.01)$ in all buffaloes (range 3-5 times). 


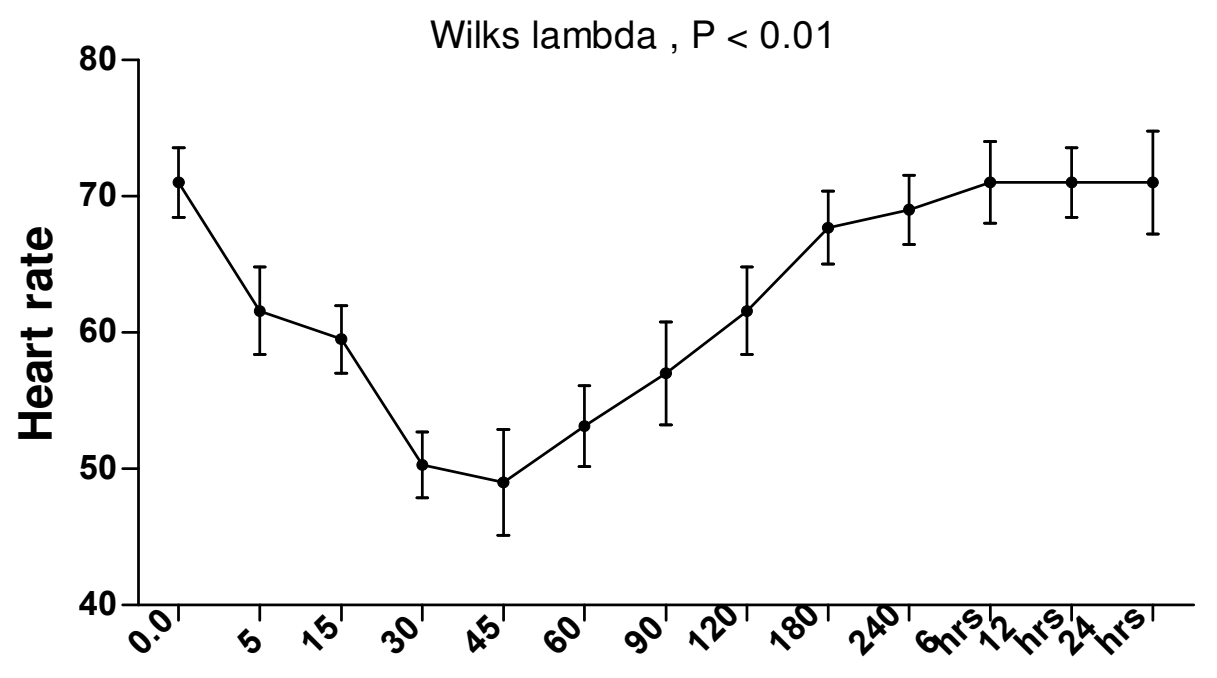

\section{Time}

Fig. (1): Heart rate in buffalo pre- and post administration of epidural romifidine at $50 \mu \mathrm{g} \mathrm{kg}^{-1}$. Note that the lowest heart rate at 45 minutes post-administraion.

All buffaloes responded with a score of zero (no analgesia) to noxious stimulation before epidural injection of romifidine. An increased threshold to skin pricks stimulation (complete analgesic effect; pain score 3), was achieved approximately 15 minutes after epidural administration of romifidine (13.00 \pm 2.51 minutes) and duration of surgery ranged from 20 to 150 minutes ( $84.75 \pm 36.76$ minutes) (Table 4$)$. There was significant increase of analgesic effect with time progress (Wilks, Lambda, $\mathrm{P}<0.01$ ) (Table 3). For all animals, the peak of the analgesic period extended from 15-240 minutes post- administration of romifidine. In one treated buffalo, the skin around the surgical incision became 
somewhat sensitive to suturing after about 100 minutes following romifidine injection. Six hours after epidural administration of romifidine, all treated buffaloes showed a very weak and occasional response to skin pricks stimulation (moderate analgesia; pain score 2). By 12 hours after epidural administration, there were no longer analgesia and all treated buffaloes responded with a score of 0 (no analgesia) to skin pricks stimulation.

Fifteen minutes after epidural administration, all buffaloes began to show signs of systemic sedation (mild sedation, score $=1$ ) (Table 4). No difference in onset was detected between all buffaloes. Maximal sedative effect (moderate sedation, score $=2$ ) occurred between 30 and 180 minutes after epidural administration of romifidine (Wilks, Lambda, $\mathrm{P}<$ 0.05, post-hoc Bonferroni, $\mathrm{P}<0.05)$. All animals remained calm and appeared to be unaware of their surroundings. Dropping (ptosis) of the eyelids and external conchea of the ear, lowering the head carriage, deviation of the neck, protrusion of the tongue from the mouth and ptyalism were recorded. Six and twelve hours after epidural administration of romifidine, all treated buffaloes remained mildly sedated with dropping lower eyelids, a decreased response to external stimuli, and lack of appetite (mild sedation, score $=1$ ). By 24 hours after epidural administration, all buffaloes were no longer sedated and were eating well. All treated buffaloes did not show any clinical evidence of ruminal tympany. Forty-eight hours after epidural administration of romifidine, one buffalo developed a transient watery diarrhea that lasted for approximately 24 hours. This diarrheic buffalo remained bright and alert with a good appetite. 
Mohamed Marzok et al.,

Table (4): Analgesic and sedative scores (Median and range) of epidural romifidine $\left(50 \mu \mathrm{g} \mathrm{kg}^{-1}\right)$ in buffaloes with abdominal and teat surgery.

\begin{tabular}{|c||c||c||}
\hline $\begin{array}{c}\text { Time } \\
\text { Post-administration } \\
\text { (minutes) }\end{array}$ & Analgesic effect & Sedative effect \\
\hline \hline Zero & $00 \pm 00^{\mathrm{a}}$ & $00 \pm 00^{\mathrm{a}}$ \\
\hline 5 & $1.4 \pm 0.70^{\mathrm{b}}$ & $1.0 \pm 0.2^{\mathrm{b}}$ \\
\hline 15 & $2.95 \pm 0.22^{\mathrm{c}}$ & $1.15 \pm 1.30^{\mathrm{b}}$ \\
\hline 30 & $2.96 \pm 0.23^{\mathrm{c}}$ & $2.0 \pm 0.0^{\mathrm{c}}$ \\
\hline 45 & $3.00 \pm 0.0^{\mathrm{c}}$ & $2.0 \pm 0.0^{\mathrm{c}}$ \\
\hline 60 & $3.00 \pm 0.0^{\mathrm{c}}$ & $2.0 \pm 0.0^{\mathrm{c}}$ \\
\hline 90 & $3.00 \pm 0.0^{\mathrm{c}}$ & $2.0 \pm 0.0^{\mathrm{c}}$ \\
\hline 120 & $3.0 \pm 00^{\mathrm{c}}$ & $2.0 \pm 0.0^{\mathrm{c}}$ \\
\hline 180 & $3.00 \pm 0.0^{\mathrm{c}}$ & $1.3 \pm 0.43^{\mathrm{b}}$ \\
\hline 240 & $2.94 \pm 0.50^{\mathrm{c}}$ & $1.0 \pm 0.18^{\mathrm{b}}$ \\
\hline 360 & $1.6 \pm 0.52^{\mathrm{b}}$ & $0.0 \pm 0.0^{\mathrm{a}}$ \\
\hline 720 & $0.0 \pm 00^{\mathrm{a}}$ & \\
\hline & & \\
\hline
\end{tabular}

Values with different superscript letters in the same column are significantly different at $\mathrm{P}<0.05$

All buffaloes developed moderate ataxia (score 2, Table 2) 1520 minutes following epidural treatment with romifidine and it lasted for up to 240 minutes. All the animals remained standing throughout the observation period. One buffalo became recumbent during suturing of the incision. After 15 minutes, the animal stood without assistance. All buffaloes had poor coordination of the hind limbs when they were walked out of the stanchions, but none of them fell down. By six hours after epidural injection, all buffaloes showed a normal gait. 


\section{DISCUSSION}

In human and animal anesthesia, epidural and spinal administration of drugs is used to provide surgical anesthesia and/or postoperative analgesia. Alpha-2 adrenoceptor agonists are becoming increasingly popular for providing intraoperative and postoperative analgesia in domestic species (Jean et al. 1990; Caulkett et al. 1993a \&b; Zaugg and Nussbaum, 1990; Nowrouzian et al. 1991; LeBlanc et al. 1988; Day et al. 1995; Popilskis et al. 1991; Fierheller et al. 2004; Kinjavdekar et al. 2007). They resulted in safe and effective analgesia and produced much less depression of motor function than that produced by lidocaine. By raising the injection volume it is possible to extend the anaesthetized area (Zaug and Nussbaum 1990; Rehage et al. 1994; Junhold and Schneider 2002).

The aim of the present study was to assess the sedative and analgesic effect of epidural romifidine for standing flank and udder surgery in buffaloes. Baseline values for all estimated variables were within normal limits for buffaloes. These observations indicate that the buffaloes were healthy and calm at the time of administration of the drug. At the given dose $\left(50 \mu \mathrm{g} \mathrm{kg}^{-1}\right)$, epidural romifidine produced significant decrease in the heart rate (Wilks' Lambda, $\mathrm{P}=0.001$ ). Bonferroni post-hoc multiple comparison test showed that the lowest value was at 60 minutes post-administration. This result is in agreement to previous studies in cattle and dogs (Massone et al. 1993; Pyppendob and Verstegen2001). Bradycardia following administration of alpha-2 adrenoceptor agonist may be due to central stimulation mediated through the vagus nerve (Hall et al. 2001). 
No significant effect on respiratory rates and the rectal temperatures of treated buffaloes was detected after epidural administration of romifidine. However, a significant decrease in the respiratory rate $(P<$ $0.05)$ was reported in cattle and goat after epidural or subarachnoid administration of romifidine (Fierheller et al. 2004; Kinjavdekar et al. 2006).

In horses, perineal sweating is a sign that alpha 2-adrenoceptor agonists had been injected correctly into the epidural space (Leblanc et al. 1988). In the present study, buffaloes showed no such sweating as evidence of proper injection. Despite that, it was not difficult to correctly place the hypodermic needle for epidural injection of these buffaloes. This was similar to that previously recorded after the use of xylazine in cattle (Zaugg and Nussbaum 1990).

The dosage of romifidine in buffaloes is not yet well established. When it was given intravenously at a dose rate of $50 \mu \mathrm{g} \mathrm{kg}^{-1}$ to buffalo calves, they become recumbent in 15 minutes and the anesthetic period lasted for approximately one hour (Shekidef et al. 2007). In the present study, a $50 \mu \mathrm{g} \mathrm{kg}^{-1}$ dose was used, based on a study in goats in which 50 and $75 \mu \mathrm{g} \mathrm{kg}-1$ romifidine were administrated in the subarachnoid space (Pablo 1993). Goats treated with $50 \mu \mathrm{g} \mathrm{kg-1}$ romifidine had similar levels of analgesia, but with less sedation and cardiovascular depression than did goats treated with $75 \mu \mathrm{gg}^{-1}$. The dose-dependent systemic effects of romifidine have been described in dogs when doses ranging from 5 to $100 \mu \mathrm{g} \mathrm{kg}^{-1}$ were administered IV (Pyppendob and Verstegen 2001). Systemic effects of romifidine were minimized by using lower doses; however, these effects were comparable when doses greater than $25 \mu \mathrm{g} \mathrm{kg}^{-1}$ were administered, suggesting a possible ceiling effect for 
romifidine. In the present study, although the buffaloes did not become recumbent, the degree of sedation documented might have been minimized if a lower dose had been used. Further research is needed to determine a romifidine dose that causes minimal systemic effects while maintaining adequate analgesic effects in buffaloes.

The total volume of the administered solution given epidurally in this study was derived from other epidural studies in cattle and the migration of new methylene blue in the epidural space of cattle, horses, goats, and calves (Caulkett et al. 1993a \&b; Lee et al. 2001; Hendrickson et al. 1998; Skarda 1996; Lopez et al. 1997; Johnson et al. 1996; Meyer et al. 2007). A total volume of $20 \mathrm{ml}$ was decided for each buffalo, in an attempt to standardize the volume for practical use by veterinarians having to estimate doses in the field. By increasing the volume of delivered drug in the epidural space, the cranial extent of migration and analgesia may be increased.

Analgesia is an important quality of alpha-2 agonists (England and Clarke 1996). These substances act on both pre-and postsynaptic alpha-2 receptors, in the central nervous system, which decrease interneuronal transmission of norepinephrine and promote sedative and analgesic effects (Hall et al. 2001). Results in the study reported here suggest that epidural administration of romifidine provides significant analgesia of flank and udder regions, which was adequate for all required surgeries. Maximal effects were present at 15 minutes and gradually decreased to baseline levels after about 6 hours. As the buffaloes were only evaluated at 6,12 and 24 hours postepidural administration, the exact duration of analgesia remains speculative. The onset of action of analgesia in this study appears to correlate well with studies on the epidural administration of romifidine in cattle (Massone et al. 1993; Fierheller et al. 2004). 
Whether the degree of analgesia produced in this study was due to local effects on the spinal cord or systemic sedation is difficult to evaluate. It has been shown that the effects of epidural versus IM administration of detomidine in cattle induce comparable degrees of analgesia. One theory for the analgesic effects observed was that IM detomidine acted on supraspinal $\alpha 2$-adrenergic receptors in the brain, while epidural detomidine had its effects locally in the spinal cord (Prado et al. 1999). However, the total volume of drug administered epidurally may not have been sufficient to achieve cranial migration of drug to the caudal lumbar and sacral spinal cord segments, thus the epidural effects in this study may also be attributable to systemic absorption and central effects in the CNS.

It was expected that epidural romifidine would produce spinal analgesia, similar to xylazine in cattle. In one study, $0.05 \mathrm{mg} \mathrm{kg}-1$ body weight epidural xylazine produce 75-180 minutes of perineal analgesia (Caron and LeBlanc 1989). The more prolonged time of effect in our study can be explained by the fact that romifidine has longer duration of action than xylazine (Hall et al. 2001).

The prolonged duration of epidural analgesia using romifidine was not without disadvantage. Systemic absorption of the romifidine is likely, as treated buffaloes often showed signs of sedation. Dosages that did not result in sedation inconsistently produced epidural analgesia. Measurement of blood concentrations of romifidine or its metabolites were not conducted in this study. A second disadvantage of epidural romifidine is the somewhat delayed onset of analgesia compared to local anesthetic drugs as lidocaine. This disadvantage may be avoided with the simultaneous use of lidocaine and romifidine, but this combination was 
not investigated in this study. However, for buffaloes in the present study, scrubbing, disinfecting, and draping of the surgical site were performed immediately after epidural administrationof romifidine (during the initial period before the onset of analgesia). Thus, surgery was begun approximately 15-20 minutes after epidural injection.

The sedative effects of romifidine at different doses and routes of administration have been studied in different animals ((England et al. 1992 \& 1996; Gasthuys et al. 1996; Kerr et al. 1996; Lemke 1999; Selmi et al. 2004; Prado et al. 1999; Fierheller et al. 2004; Celly et al. 1997; Aithal et al. 2001; Kinjavdekar et al. 2002; Kinjavdekar et al. 2006): however, there is no reported study on the use of romifidine for epidural analgesia in buffaloes. Our study indicated that romifidine is capable of producing systemic sedation (mild sedation, score=1). Onset of sedation started soon (10 minutes) after epidural injection of romifidine. No difference in onset was detected between all buffaloes. Our findings describing the sedation qualities of romifidine in buffaloes are similar to those reported for cattle and goats after epidural administration of romifidine and xylazine (Caron and LeBlanc 1989; Zaugg and Nussbaum 1990; Fierheller et al. 2004; Kinjavdekar et al. 2006). Sedation occurs following the absorption of epidurally administrated drugs into the vascular system (Gomez de Segura et al. 1998; Robinson and Natalini 2002) or transfer from the cerebral spinal fluid (Pedraz et al. 1991). Slow systemic absorption from the epidural space explains why romifidine produced mild sedation and did not produce recumbency, as would be expected if the same dose was used IV.

Ataxia was commonly observed in horses and cattle following epidural injection of xylazine and was attributed to the local anesthetic 
properties of such analgesic agent (Leblanc et al. 1988; Caron and Leblanc 1989). A similar mechanism may have been responsible for the ataxia observed in this study. The combined systemic effects of muscle relaxation and sedation could be responsible for the ataxia observed in our study. High doses of alpha 2-adrenoceptor agonists have been shown to produce hind limb flaccidity in rats (Yaksh 1985). Ataxia may be less problematic with the availability of more selective alpha 2-adrenoceptor agonists.

Excessive salivation was recorded in this study. Similarly, cattle given romifidine had obvious increases in salivation (Fierheller et al. 2004). The marked increase in urine production after administration of alpha-2 agonists thought to be through inhibition of antidiuretic hormone release and hyperglycemia (Hall et al. 2001).

Although, it was proved that alpha-2 agonists (xylazine, detomidine and romifidine) exert a marked pressure increase in the mare uterus (Schatzmann et al. 1994), it has not yet been established whether romifidine is safe for use in pregnant buffaloes or other animal species.

The economic factors associated with analgesic administration of romifidine in food animals must be taken in consideration. The cost of romifidine for epidural administration was double the cost of lidocaine required for a local nerve block of the flank region (EGP 45 versus EGP 22). Although the romifidine is expensive, the benefits of sedation and postoperative analgesia may outweigh the difference in price. Comparing the cost of epidural analgesia with the cost of nonsteroidal antiinflammatory drugs labeled for use in cattle, a significant economic benefit is apparent with the use of epidural analgesics. 


\section{CONCLUSIONS}

The present study showed that the clinical use of epidural romifidine can be indicated when long-term moderate analgesia is desired. Epidural administration of romifidine provides adequate analgesia for abdominal and udder surgery in buffalo, while allowing the patients to remain standing. The side effects of epidurally administrated romifidine were acceptable and had a little influence on the procedures or on recovery. Therefore, romifidine might be promising as an analgesic agent for buffaloes even for major abdominal surgery. Although a dosage of $50 \mu \mathrm{g} \mathrm{kg}^{-1}$ was efficient and safe, further studies were needed to be done onto spinal toxicity; withdrawal times, systemic effects, and potential adverse using different doses before recommending the safely clinical use of romifidine.

\section{REFERENCES}

- Adams HR (2001): Veterinary pharmacology and therapeutics. $8^{\text {th }}$ Ed. Iowa, Iowa State Univ Pr, pp323-324.

- Amarpal, Kinjavdekar P, Aithal HP, Pawde AM, Pratap K. (2002): Analgesic, sedative and hemodynamic effects of spinally administered romifidine in female goats. J Vet Med Assoc 49, 3-8.

- Aithal HP, Amarpal KP, Pawde AM, Pratap K (2001): Analgesic and cardiopulmonary effects of intrathecally administered romifidine or romifidine and ketamine in goats(Capra hircus).J S Afr.Vet.Assoc,72, 84-91.

- BENSON GJ, THURMON JC (1981): Regional analgesia of food animals. In: Howard JL,ed. Current Veterinary Therapy Food Animal Practice. Philadelphia: W.B. Saunders, pp 2-81. 
- Caron J P, LeBlanc PH (1989): Caudal epidural analgesia in cattle using xylazine. Can J Vet Res 53, 486-489.

- Caulkett NA,Cribb PH, Duke T (1993a): Xylazine epidural analgesia for cesarean section in cattle. Can Vet J 34, 674-676.

- Caulkett NA, Cribb, P H, MacDonald DG, Fretz PB, Janzen ED (1993b): Xylazine hydrochloride epidural analgesia: A method of providing sedation and analgesia to facilitate castration of mature bulls. Compend Contin Educ Pract Vet 15, 1155-1159.

- Celly CS, McDonell WN, Young SS, et al. (1997): The comparative hypoxaemic effect of four alpha-2 adrenoceptor agonists (xylazine, romifidine, detomidine and medetomidine) in sheep. J Vet Pharm Ther 20, 464-471.

- Cousins MJ, Mather LE (1984): Intrathecal and epidural administration of opioids. Anesthesiology, 61: 276-310.

- Day TK, Pepper WT, Tobias TA, et al. (1995): Comparison of intraarticular and epidural morphine for analgesia following stifle arthrotomy in dogs. Vet Surg 24, 522-530.

- England GC, Clarke KW, Goossens L (1992): A comparison of the sedative effects of three alpha 2-adrenoceptor agonists (romifidine, detomidine and xylazine) in the horse. J Vet Pharmacol Ther 15, 194201.

- England GC, Andrews F, Hammond RA (1996): Romifidine as a premedicant to propofol induction and infusion anaesthesia in the dog. J Small Anim Pract 37, 79-83.

- England GC, Clarke KW (1996): Alpha-2 adrenoceptor agonists in the horse- a review. Br Vet J 52, 651-57. 
- Fierheller EE, Caulkett NA, Bailey JV (2004): A romifidine and morphine combination for epidural analgesia of the flank in cattle. Can Vet J 45, 917-923.

- Gasthuys F, Martens A, Goossens L, De Moor A. (1996): Quantitative and qualitative study of the diuretic effects of romifidine in the horse. J Vet Anest 23, 6-10.

- Gomez De Segura IA, Tendillo FJ, Marsico F, Cediel R (1993): Alpha-2 agonists for regional anaesthesia in the cow. J Vet Anaesth 20, 32-33.

- Hall LW, Clark KW, Trim CM (2001): Veterinary Anesthesia. 10th Ed. W. B. Saunders, London, UK pp83-91.

- Hendrickson DA,Southwood LL,Lopez MJ,Kruse-Elliott KT (1998): Cranial migration of different volumes of new-methylene blue after caudal epidural injection in the horse. Equine Pract 20, 12-14.

- Ishii H, Kohno T, Yamakura T, Ikoma M, Baba H (2008): Action of dexmedetomidine on the substantia gelatinosa neurons of the rat spinal cord. Eur J Neurosci 27, 3182-90.

- Jean G, Skarda RT, Muir WW, Hoffsis GF (1990): Caudal epidural analgesia induced by xylazine administration in cows. Am J Vet Res $51,1232-1236$.

- Johnson RA, Lopez MJ, Hendrickson DA, Kruse-Elliott KT (1996): Cephalad distribution of three differing volumes of new methylene blue injected into the epidural space in adult goats. Vet Surg 25, 448451.

- Jöchle W, Hamm D (1986): Sedation and analgesia with Domosedan in horses: Dose response studies on efficacy and duration. Acta Vet Scand 82, 68-84. 
- Junhold J, Schneider J (2002): Untersuchung zur Analgetischen Wirkung des a2-Agonisten Xylazin (Rompun) nach epiduraler Applikation beim Rind. Tier a“ rztl Prax 30, 1-7.

- Kerr CL, McDonell WN, Young SS (1996): A comparison of romifidine and xylazine when used with diazepam/ketamine for short duration anesthesia in the horse. Can Vet J 37, 601-9.

- Kinjavdekar AP,Aithal HP,Pawde AM, Pratap K (2002): Analgesic, sedative and haemodynamic effects of spinally administered romifidine in female goats. J Vet Med A Physiol Pathol Clin Med 49, 3-8.

- Kinjavdekar P, Aithal HP, Amarpal S, Pawde AM, Pratap K, Singh $\boldsymbol{G R}(2006)$ : Potential effect of romifidine with lidocaine administration in goats. Small Ruminant Res 64, 293-304.

- Kinjavdekar P, Singh GR, Amarpal S, Aithal HP, Pawde AM (2007): Clinicophysiological effects of spinally administrated ketamineand its combination with xylazine and medetomidine in healthy goats. Vet. Res. Commun. 8, 15-22.

- LeBlanc PH, Caron JP, Patterson JS, Brown M (1988): Epidural injection of xylazine for perineal analgesia in horses. J Am Vet Med Assoc193, 1405-1408.

- Lee I, Soehartono RH, Yamagishi $N$ (2001): Distribution of new methylene blue injected into the dorsolumbar epidural space in cows. Vet Anesth Analg 28,140-145.

- Lemke KA (1999): Sedative effects of intramuscular administration of a low dose of romifidine in dogs. Am J Vet Res 60(2), 162-8.

- Lee I, Yamada, H (2005): Epidural administration of fixed volumes of xylazine and lidocaine for anesthesia of dairy cattle undergoing flank surgery. JAVMA 227, 781-784. 
- Levy RH (1974): Local anesthetic structure, activity and mechanism of action. In: Eger El, ed. Anesthetic Uptake and Action. Baltimore: Williams \& Wilkins,: 323-331.

- Lewis CA, Constable PD, Huhn JC, Morin DE ( 1999): Sedation with xylazine and lumbosacral epidural administration of lidocaine and xylazine for umbilical surgery in calves. J AmVet Med Assoc 214, 89-95.

- Lopez MJ, Johnson R, Hendrickson DA, Kruse-Elliott KT (1997): Craniad migration of differing doses of new methylene blue injected into the epidural space after death of calves and juvenile pigs. Am $\mathbf{J}$ Vet Res 58,786-790.

- Massone F, Luna SP, Castro GB, Meneghello JL, Lopes RS (1993): Sedation with romifidine or xylazine in cattle, is it the same?. J Vet Anesth 20, 55.

- Meyer H, Starke A, Kehler W, Rehageesth J (1993): High Caudal Epidural Anaesthesia with Local Anaesthetics or a2-Agonists in Calves. J Vet Med A 54, 384-389.

- Natalini C, Driessen B (2007): Epidural and Spinal Anesthesia and Analgesia in the Equine. Clinical Techniques in Equine Practice145153.

- Nowrouzian I, Adib-Hashemi A, Ghamsari SM, Kavoli-Haghighi M (1991): Evaluation of epidural analgesia with xylazine HCL in cattle. Vet Med Rev 61, 13-17.

- Pablo LS(1993): Epidural morphine in goats after hindlimb orthopedic surgery. Vet Surg 22, 307-310. 
- Pedray JL, Calvo MB, Gascon AR, et al. (1991): Pharmacokinetics and distribution of ketamine after extradural administration to dogs. Br J Anaesth 67, 310-316.

- Popilskis S, Kohn D, Sanchez JA, Gorman P (1991): Epidural vs. intramuscular oxymorphone analgesia after thoracotomy in dogs. Vet Surg 20, 462-467.

- Prado ME, Streeter RN, Mandsager RE, Shawley RV, Claypool PL (1999): Pharmacologic effects of epidural versus intramuscular administration of detomidine in cattle. Am J Vet Res 60, 1242-7.

- Pypendop BH, Verstegen JP (2001): Cardiovascular effects of romifidinen in dogs. Am J Vet Res 62, 490-495.

- Robinson EP, Natalini CC (2002): Epidural anesthesia and analgesia in horses. Vet Clin North Am Equine Pract 18, 61-82.

- Schatzmann U, Jossfck H, Stauffer JL, Goossens L (1994): Effects of alpha 2-agonists on intrauterine pressure and sedation in horses: Comparison between detomidine, romifidine and xylazine. Zentralbl Veterinaermed A 41, 523-9.

- Selmi AL, Barbudo-Selmi GR, Mendes GM, Figueiredo JP, et al. (2004): Sedative, analgesic and cardiorespiratory effects of romifidine in cats. Vet Anaesth Analg 31, 195-206.

- Seiferle $\boldsymbol{E}$ (1992): Zentralnervensystem, Rückenmark. In: Nickel, R., A. Schummer, and E. Seiferle (eds), Lehrbuch der Anatomie der Haustiere, Vol. 4, 3rd edn. Paul Parey, Berlin, Hamburg, Germany. 
- Shekidef M, Al-akraa, A, Ghanem, M (2007): Studies on the effect of medetomidine versus romifidine in buffalo calves. Assiut Vet Med J 53, 291-309.

- Skarda RT (1986): Techniques of local analgesia in ruminants and swine. Vet Clin North Am 2, 621-663.

- Skarda RT (1996): Local and regional anesthetic techniques: ruminant and swine. In: Thurmon JC, Tranquilli WJ, Benson GJ, Lumb VL (Eds), Veterinary Anesthesia. Balimore: The Wilimas \& Wilkins Co, pp479-414.

- Skarda RT, Muir WW (1979): Segmental lumbar epidural analgesia in cattle. Am J Vet Res 40, 52-57.

- Skarda RT, Muir WW (1992): Physiologic responses after caudal epidural administration of detomidine in horse and xylazine in cattle. In: Short, C.E., Poznak, A.V. (Eds.), Animal Pain. Churchill Livingstone, New York, pp. 292-302.

- Turner AS, McIlwraith CW (1982): Techniques in Large Animal Surgery. Philadelphia: Lea \& Febiger, pp12-13.

- Yaksh TL (1985): Pharmacology of spinal adrenergic systems which modulate spinal nociceptive Processing. Pharmacol Biochem Behav $22,845-858$.

- Zaugg JL, Nussbaum M (1990): Epidural injection of xylazine: A new option for surgical analgesia of the bovine abdomen and udder. Vet Med 80,1043-1046. 
Mohamed Marzok et al.,

حقن عقار الروميفيدين فوق الام الجافية فى الجاموس لاحداث تخلير جراحى يمكن من اجراء

\section{جراحات منطقة الخاصرة والضرع فى وضعية الوقوف}

محد عبل المنعم مزرقق ، شعبان محد جاد الله ،صبرى الخضرى ، مايسة انور

لقد كان الغرض من هذه الدراسة هو تقييم قدرة عقار الروميفيدين كعقار يمكن حقنة فوق الام الجافية لإجر اء جر احات منطقة الخاصرة و الضر ع فى وضعية الوقوف فى الجاموس.

استخدم عدد عشرون من انثى الجاموس تم اجراء جراحات لهم فى منطقة الخاصرة و الضرع .تم حقن عقار الروميفيدين بجرعة مقدارها 50 ميكروجر ام/كجم في الفر اغ فوق آلام الجافية بين أول وثاني فقرة عصعصية فى كل الحيو انات وهى تامة الإفاقة وفى وضعية الوقوف. تم تسجيل البيانات الخاصة ببدء الإحساس بفق الألم ، حدود منطقة فقد الإحساس بالألم ، التأثثرات العامة للعقار ، والوقت المستغرق لإجر اء الجر احة لكل حيوان علاوة على ذلك نم قياس

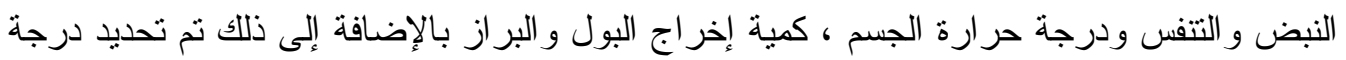
فقد الإحساس بالألم ، السكون و الاتزان على فتر ات زمنية قبل وبعد الحقن.

وقد أظهرت الدراسة أن حقن عقار الروميفيدين قد احدث انخفاض معنوي في ضربات القلب

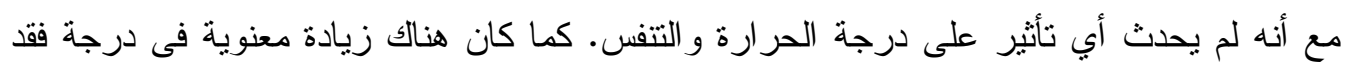
الإحساس بالألم مع مرور الوقت و التي وصلت إلى أعلى معدلاتها في الفترة ما بين 15 و 240 دقيقة

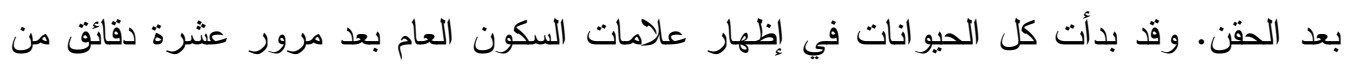
الحقن (سكون معتدل من الدرجة الأولى) وكان أعلى تأثير للسكون فى الفترة ما بين 30-180 دقيقة

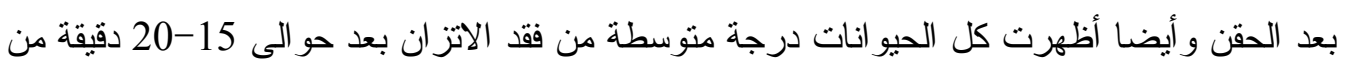
الحقن و التي استمرت إلى 240 دقيقة بعد الحقن. من كل هذه النتائج يتضح أنه يمكن استخدام هذه الطريقة كطريقة آمنة وغير مكلفة لإحداث تخدير جر احي لمنطقة الخاصرة و الضر ع يمكن من إجر اء الجراحات في هذه المناطق في وضعية الوقوف. كما أن استخدام عقار الروميفيدين في هذه الدراسة لهنة يثير أنه يمكن استخدامه لإجر اء جر احات البطن الكبرى في الجاموس. 